\title{
PENATAAN PEDAGANG KAKILIMA (PKL) DI KAWASAN TAMAN RIA PALU
}

\author{
Nindyo Soewarno') \& Muhammad Bakri2) \\ 1)Professor \& 2)Mahasiswa Program Doktor \\ Pascasarjana Universitas Gadjah Mada Yogyakarta
}

\begin{abstract}
The matter of retail traders (PKL) is one of the classical problems that always be a problem for an area or region at it results a bad image for the area where which they take place. Such a condition happens in Taman Ria Palu area. The condition has caused bad effect that is especially in the space usage of the area, uncontrolled growth and no specific form for PKL. Such a condition must be solved through out research that emphasizing at the form and the use of the space of the area by PKL It is in order to identify the problems of the element of the problems so that can help the development of the area. The advantage of the research is so that the PKL do not become a problem for the element of the area they take place but to find a solution point of the problem at the area that have a link with PKL's activities. It's can be a contribution for the government to arrange the government regulation. The analysis of this research employs the theory of need of that people in visiting the area (park) and see the PKL as one of the components of the space order together with the other ones. The frame of the theory that used is by observing the interaction among public area, public activity, and the activity of all PKL in using the area. This research is using the method of descriptive qualitative quantitative paradigm that explain the qualitative data in form of matrix, picture to find out the parameter, variable, and the research indicator based on the frame of theory. The result of the research that have link with the pattern of the development of PKL is uncontrolled, activity as the respond of the growth, and the intraction among elements of the area strongly effects the need of people for visiting the area (the park). The factor influenced the use of the are must reviewed in the terms of designing patterns for solving the problem.
\end{abstract}

\section{PENDAHULUAN}

\section{Latar Belakang}

Tampak bahwa antara manusia dengan latar belakang budaya dan persepsinya saling membentuk pola lingkungannya sehingga dapat mengakomodasi pola kebutuhan fisik, secara keseluruhan membentuk pola lingkungan spesifik dalam lingkup ruang (Rapoport, 1997), yang dibagi menjadi 2 ruang yaitu Public space dan Privat space yang diinter-pretasikan dari kecendrungan spasial kolektif dan individual (Hertzberger, 1991).
Kondisi ini sering terjadi pada kawasan publik dimana terdapat ruang yang di fungsikan secara privat oleh sekelompok atau beberapa orang sebagai ekspresi maupun aksentuasi diri terhadap penguasaan ruang. Taman Ria sebagai salah satu contoh kasus mengakomodasi kepentingan bersifat publik terletak di kawasan pinggiran Teluk Palu. Beberapa aktivitas layanan publik di kawasan tersebut yaitu berupa pelayanan sektor informal dan formal tumbuh tidak saling menunjang. 
Kecenderungan dominasi PKL mematikan sektor formal dan beberapa potensi kawasan yang disebabkan tidak adanya format penataan serta kebijakan pemerintah daerah dalam pemanfaatan kawasan tersebut. Kelemahan stakeholder terkait dalam pengambilan kebijakan pegembangan kawasan merang-sang perkembangan tanpa arah. Sehingga pertumbuhan PKL di Kawasan menimbulkan masalah barn, sebab pola perkembangan kios PKL secara semi permanen dengan pola linier mengikuti garis pantai mengganggu kenyamanan pandang ke arah pantai.

Kondisi ini menyebabkan tertutupnya arah pandang ke arah teluk menyaksikan bermacam atraksi alam serta kegiatan nelayan yang berlangsung setiap saat, sebagai atraksi fenomena budaya yang menyatu dengan alam sangat menarik. Persoalan tersebut merupakan tantangan untuk bagaimana mengarahkan PKL di kawasan taman publik sehingga tidak mematikan potensi kawasan. Sebagaimana Heintz (1997), yang menyatakan keberadaan perdagangan komersial, pemasaran public space untuk menarik para pelanggan menawarkan suatu cita rasa yang benar-benar bagus dan orang dapat merasakan keamanan dan kenyamanan selama mengkonsumsi dan memanfaatkan daerah tersebut.

\section{Rumusan Masalah}

Permasalahan yang terungkap di atas memunculkan isu-isu yang terkait dengan taman publik dan pedagang kakilima (PKL) yaitu : (a) Di kawasan Taman Ria tumbuh kegiatan komersial pedagang kaki lima (PKL) yang mendominasi aktivitas serta penggunaan ruang kawasan tanpa arahan dari Pemerintah Daerah dan (b) Dominasi aktivitas pedagang kaki lima (PKL) di pinggiran pantai menja-dikan pantai sebagai back area serta pendirian kios menghalangi pandangan ke laut sebagai amatan alami di kawasan (natural view area).

Tidak adanya keterkaitan antara elemen fisik/non fisik serta sektor formal/informal sehingga perkembangan kawasan cenderung tidak terkontrol. Untuk mengarahkan perkembangan kawasan, maka tahap selanjutnya diperlukan pertanyaan penelitian yang dapat membantu mencari variabel-variabel penelitian melalui tinjauan pustaka yang berkaitan dengan perumusan masalah.

\section{Tujuan Penelitian}

Tujuan yang ingin dicapai dalam penelitian ini adalah (i) menggambarkan eksisting kawasan Taman Ria sebagai kawasan taman publik untuk anak-anak dengan aktivitas pedagang kakilima (PKL) di dalamnya, (ii) mengidentifikasi pengaruh aktivitas pedagang kakilima (PKL) terhadap pemanfaatan ruang dan elemen di Kawasan Taman Ria Palu untuk mengetahui kebutuhan ruang dan pengguna sebagai parameter arahan desain pedagang kakilima di kawasan taman publik.

\section{TINJAUAN PUSTAKA}

Tinjauan pustaka dilakukan sebagai salah satu cara mengidentifikasi penyelesaian masalah melalui literatur untuk menemukan teori pelaksanaan pemecahan masalah yang berhubungan dengan Penataan Pedagang Kakilima (PKL) di Kawasan Taman Ria Palu. "Kumar dalam Internatinal Symposium
on Asian Pacific Architecture (1997),
melihat fungsi dari taman publik hams
dapat mewadahi cita rasa tempat, dan
kualitas kehidupan sehingga para
pengunjung dapat berjalan-jalan dan
betah di tempat tersebut". Desain 
taman publik hams memasukkan jaringan infrastruktur di dalamnya seperti transportasi, listrik, gas, air saluran air dan telekomunikasi dapat digunakan oleh pengunjung. Sebab dalam perkembangannya ruang publik sebagai tempat orang-orang berhenti, beristirahat dan melepaskan diri dari kebingungan, kebisingan, kemacetan dan kepadatan (overload) di sekelilingnya. Dalam hal ini taman publik menjadi tempat persinggahan atau semacam stimulus shelter. Sehingga dapat menyediakan sebuah situasi kontras dengan lingkungan di luarnya (out site). Kondisi ini merupakan kepuasan periodik yang dibutuhkan orang di suatu taman guna mengumpulkan kembali tenaga mereka sebelum melanjutkan aktivitasnya.

Nager et. All (1992) di Bryant Park mengklasifikasikan alasan orang mengunjungi taman adalah untuk santai, kenyamanan, sumber ketenangan (relaxation, comfortable, tranquil), sumber ketenangan masyarakat yang damai serta tempat perlindungan lingkungan atau cagar alam demikian juga pada taman Greenacre Park dan Manhatam Green Area. Ruang publik selain menawarkan rutinitas keseharian yang kontras juga menawarkan transisi dari kehidupan dunia kerja menjadi kehidupan yang santai (leisure). Temuan tersebut menunjukkan adanya kesamaan fungsi atau aktivitas yang berlangsung di taman dimana keberadaan ruang publik atau taman publik sangat dibutuhkan sebagai suatu kawasan peralihan aktivitas keseharian yang menawarkan cita rasa yang berbeda dengan kegiatan kota di mana pengunjung dapat beristirahat sambil menikmati makanan/ minuman serta atraksi yang ditawarkan baik sifatnya alam berhubungan dengan Teluk Palu maupun buatan.
Dari tinjauan pustaka dapat ditarik kategorisasi variabel penelitian yang meliputi dua variabel yaitu : Variabel fungsi yaitu aktivitas pedagang kakilima (PKL) di taman publik, seting fisik kawasan, serta pola kegiatan. Sedangkan variabel yang mendorong adanya kegiatan pedagang kakilima (PKL) di taman publik yaitu adanya aktivitas publik, suasana yang bersifat alami, rekreatif dan faktor ekonomi.

Ruang terbuka publik dapat memberi rangsangan tumbuhnya aktivitas publik movement dan non-movement baik bersifat individu maupun kelompok dari aktivitas tersebut direspon pertumbuhan aktivitas pedagang kakilima (PKL) yang mendapat keuntungan dari aktivitas publik, sehingga dalam penataan/perancangan ruang publik harus merespon/ mengakomodasi akan pertumbuhan aktivitas lain dalam hal ini di antaranya adalah pedagang kakilima (PKL). Gambar 1 berikut menunjukkan Landasan Teori Interaksi Antara Ruang Publik, Aktivitas Publik dan Aktivitas Pedagang Kakilima.

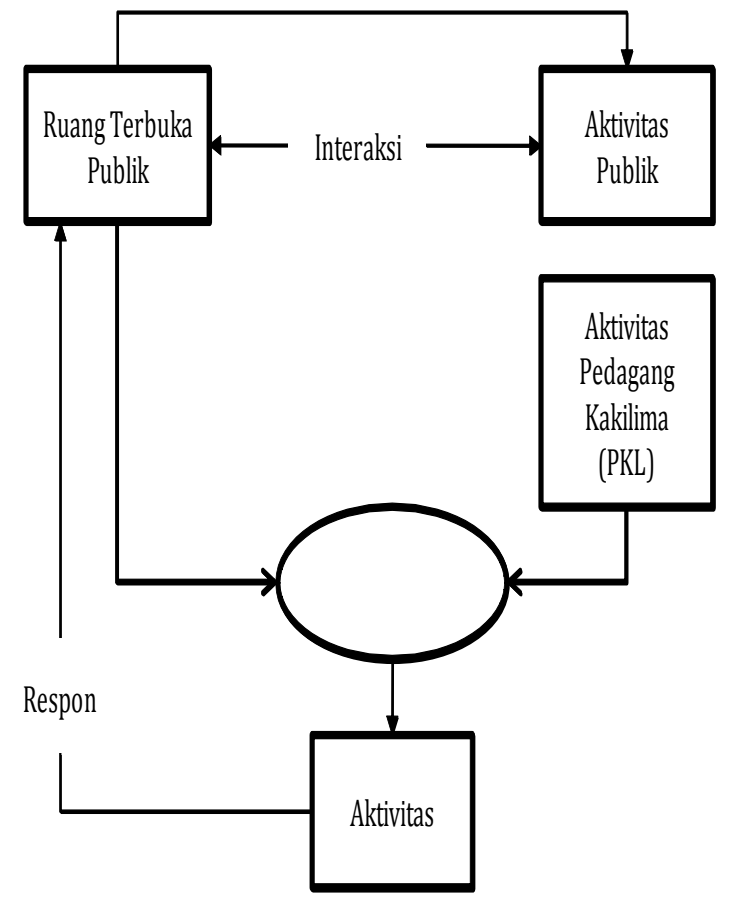




\section{METODOLOGI}

\section{Metode Penelitian}

Untuk memudahkan jalannya penelitian data yang berkaitan dengan cakupan kegiatan/aktivitas diidentifikasi menggunakan penelitian deskriptif kualitatif dengan paradigma kuantitatif yaitu mendeskripsikan data kualitatif dalam bentuk matriks, gambar ataupun grafik analog (Miles dan Huberman dalam Muhajir,2000). Data cakupan setting fisik kawasan diidentifikasi dengan metoda place centered mapping digunakan untuk mempetakan pola aktivitas serta kecenderungan baik individu maupun kelompok sebagai usaha mengakomodasi perilaku di dalam kawasan berdasarkan waktu yang telah ditentukan.

\section{Cara Pelaksanaan Penelitian}

Pengamatan dilakukan dengan membagi dua fokus amatan sebab Kawasan Taman Ria telah terbagi dua oleh jalan wisata yang melalui kawasan. Zona amatan pertama yaitu kawasan yang tidak bersentuhan langsung dengan zona pertama terdapat 1 blok (blok D) sedangkan zona kedua terdapat 3 blok (blok A,B dan C). Waktu pengamatan disesuaikan dengan waktu kunjungan (waktu luang/jam istirahat) oleh sebab itu amatan dilakukan pada waktuwaktu tertentu yaitu berlangsungnya kegiatan.

\section{HASIL PENELITIAN DAN PEMBAHASAN}

\section{Analisis Waktu Berlangsungnya Aktivitas}

Dari grafik kunjungan di atas terlihat bahwa kunjungan pada hari kerja/ tidak libur dominan berlangsung mulai pukul 15.00 sampai dengan pukul 00.00 , grafik tertinggi yaitu pukl 20.00 sampai dengan pukul 00.00. Sementara grafik kunjungan pada hari Minggu (libur) mulai mulai pada pukul 05.00 sampai dengan pukul 11.00 untuk selanjutnya pada sore hari berlangsung seperti hari kerja. Grafik kunjungan tertinggi pada hari Minggu yaitu berkisar pada pukul 07.00 sampai dengan pukul 09.00.

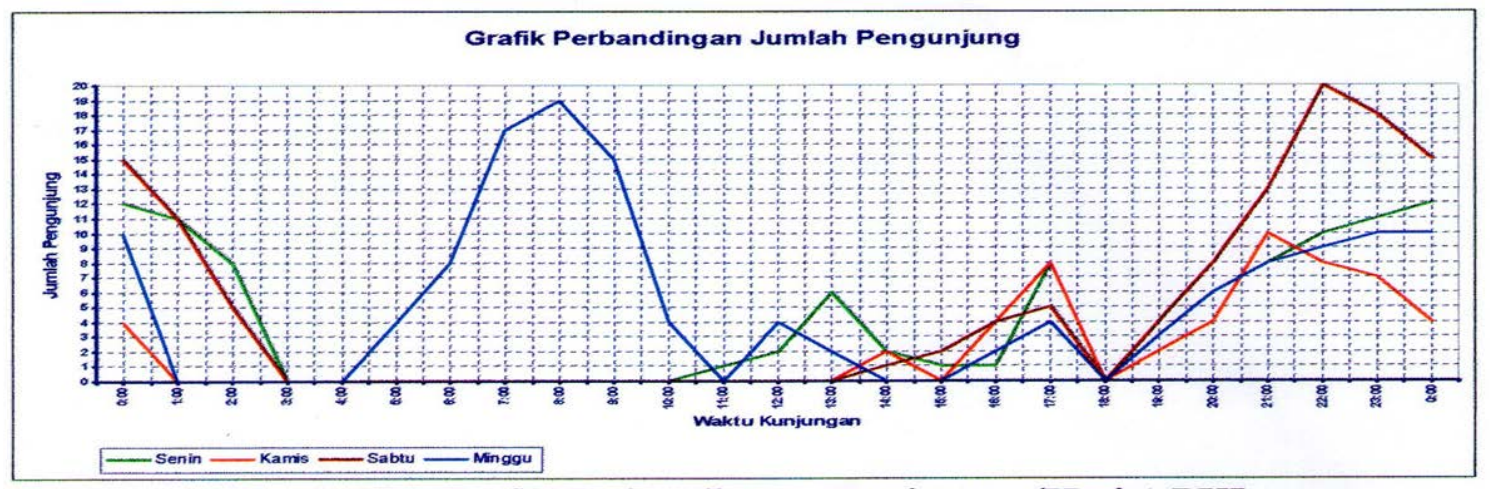

Gambar 3. Grafik Perbandingan Kunjungan/Hari 1 PKL Sumber : Hasil analisis peneliti, 2004

laut dengan pola aktivitas cenderung stagnan. Zona amatan kedua, merupakan kawasan yang berada di pinggiran pantai dengan pola aktivitas yang ramai. Dari pembagian zona tersebut dibagi lagi menjadi 4 blok kawasan masing-masing dengan estimasi di
Aktivitas secara keseluruhan pagi hari hingga malam hari berlangsung dengan akses bersentuhan langsung dengan dengan pantai. Kegiatan berupa jalanjalan, olahraga, bermain pasir, berenang, memancing (movement) serta bersantai, duduk, melihat pemanda- 
ngan, membaca, minum ataupun makan (non movement).

Dari skema tempat berlangsungnya aktivitas di atas terlihat kecenderungan aktivitas labih banyak bersentuhan langsung dengan pantai yang terdiri dari kegiatan movement dan non movement, Ashihara (1970). Permasalahannya adalah aktivitas yang berlangsung tidak didukung dengan ruang aktivitas, perkembangan kios PKL ke arah belakang semakin mempersempit ruang aktivitas pengunjung. Aktivitas di taman cenderung ditinggalkan dengan adanya pengembangan kios PKL di kawasan inti taman.

Kebutuhan pengunjung yaitu berupa ruang tempat melakukan aktivitas, olahraga, jalan-jalan, memancing (movement). Sedangkan kegiatan lainnya yaitu bersantai, duduk, melihat pemandangan, membaca, berbaring, minum ataupun makan (non movement).

\section{Analisis Pola Pemanfaatan Ruang Mikro oleh PKL}

Pola Perkembangan ruang oleh PKL makanan dan minuman dipengaruhi tuntutan pengunjung akan ketersediaan ruang yang aman dan nyaman dalam menikmati makanan / minuman. Ketertarikan terha- bagi pengunjung khususnya kenyamanan pandang, akses, serta kebebasan mengekspresikan diri. Beberapa perkembangan juga mengarah sebagai tempat tinggal sekaligus tempat jualan..

Perkembangan mikro kios PKL di kawasan blok A menimbulkan permasalahan karena adanya tuntutan akan kebutuhan pengunjung. Perkembangan tanpa arahan misalnya pengembangan kearah pantai sehingga menimbulkan penyempitan ruang tempat melakukan aktivitas movement and non movement. Pengembangan ke arah samping menghalangi akses menuju area pinggiran pantai. Penggunaan dinding papan menjadi penghalang pandangan dari arah depan sehingga praktis untuk menyaksikan pemandangan pantai harus ke belakang kios. Di blok A terdapat empat macam perubahan yang signifikan yaitu penggabungan kios menjadi satu, ke arah belakang, ke samping satu sisi dan ke samping dengan 2 sisi kiri dan kanan.

Perkembangan mikro kios PKL di kawasan blok B terdiri dari pengembangan dengan penggabungan, ke arah belakang serta ke arah samping kiri dan kanan. Permasalahan yang ditimbulkan adalah penyempitan ruang tempat melakukan aktivitas movement and non move-

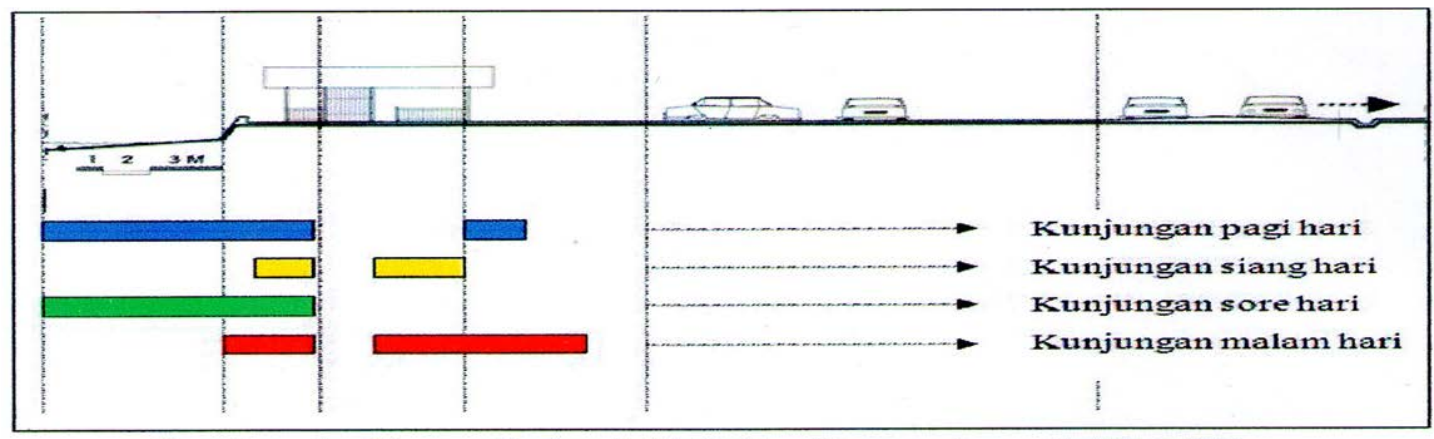

Gambar 4. Skema Lokasi Aktivitas Pengunjung Sekitar Kios Sumber : Hasil analisis peneliti, 2004

dap suasana lingkungan alami juga menjadi pengembangan dengan penguasaan ruang publik menjadi ruang privat berakibat pada kurangnya Kenyamanan ment. Pengembangan kearah samping kiri dan kanan serta ke belakang menghalangi akses menuju area pinggiran pantai tempat yang menyediakan panorama alam. 
Penggunaan dinding papan semi permanen menjadi penghalang pandangan dari arah depan ke arah pantai sehingga praktis untuk menyaksikan pemandangan pantai harus ke belakang kios.

Perkembangan mikro kios PKL di kawasan blok $\mathrm{C}$ cenderung sangat sederhana tidak bervariasi karena umumya juga yang belum begitu lama (lihat analisis perkembangan). Perkembangan hanya mengarah ke pantai (belakang). Permasalahan yang ditimbulkan adalah penyempitan ruang tempat melakukan aktivitas movement and non movement khusus- nya kegiatan yang berhubungan langsung dengan pantai. menyaksikan pemandangan pantai hams ke belakang kios.

Pengembangan kios di kawasan blok D sampai saat berlangsungnya penelitian belum terlihat sebab sebagian besar belum ditempati oleh pedagang kakilima (PKL) untuk berjualan. Analisa perkembangan mikro memperlihatkan adanya perbedaan di blok A, B, C dan D. Perkembangan banyak terjadi khususnya di blok A dan B umumnya disebabkan semakin ramainya kunjungan di kawasan.

Permasalahan yang timbul adalah pengembangan ke arah belakang dan kesamping menjadikan ruang tempat melakukan aktivitas bergerak dan tidak

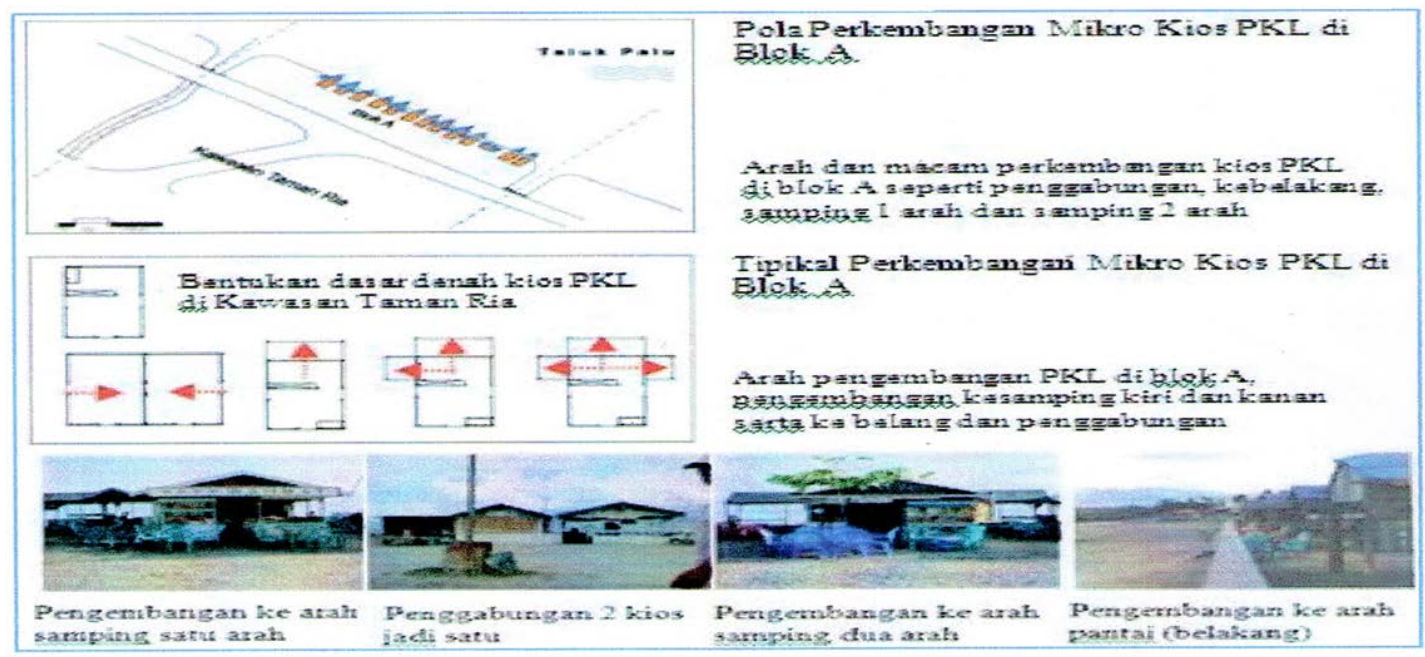

Gambar 5. Tampak Perkembangan Mikro Kios PKL di Blok A

Sumber : Hasil analisis peneliti, 2004

Pengembangan kearah samping tidak terdapat sehingga akses ke arah belakang kios tidak bermasalah sebab tidak terhalang pengembangan ke samping. Permasalahan akses terdapat di bagian belakang seperti halnya di blok A dan B karena pengembangan ke arah belakang sehingga kegiatan berupa jalan sambil menikmati pemandangan tidak dapat dilakukan. Penggunaan dinding papan menjadi penghalang pandangan dari arah depan sehingga praktis untuk bergerak sebagai tempat bersantai terinterfensin pengembangnan pemanfaatan ruang, untuk mendapatkan akses yang dibagi dalam dua kategori yaitu akses pencapaian dan akses pandang semakin semakin sempit serta pengembangan dinding kios dari papan menyebabkan pandangan terhalang dan alur sirkulasi pergerakan/pencapaian antara ruang semakin tidak jelas.

Pengembangan mikro menimbulkan konflik sebab dan analisa aktivitas baik 
berupa aktivitas bergerak (movement) maupun aktivitas tidak bergerak (nonmovement) dalam bentuk individu maupun kelompok cenderung berlangsung di bagian belakang kios yaitu area yang bersentuhan langsung dengan kawasan pantai. Kecenderungan ini sangat dipengaruhi kebuthuhan pengunjung akan suasana lingkungan yang menawarkan panorama alam Teluk Palu. Oleh karena itu pengembangan mikro kios pedagang kaki lima (PKL) harus memperhatikan normanorma lingkungan karena Kenyataan menunjukkan bahwa alam Teluk Palu merupakan salah satu objek yang menarik pengunjung di Kawasan Taman Ria Palu.

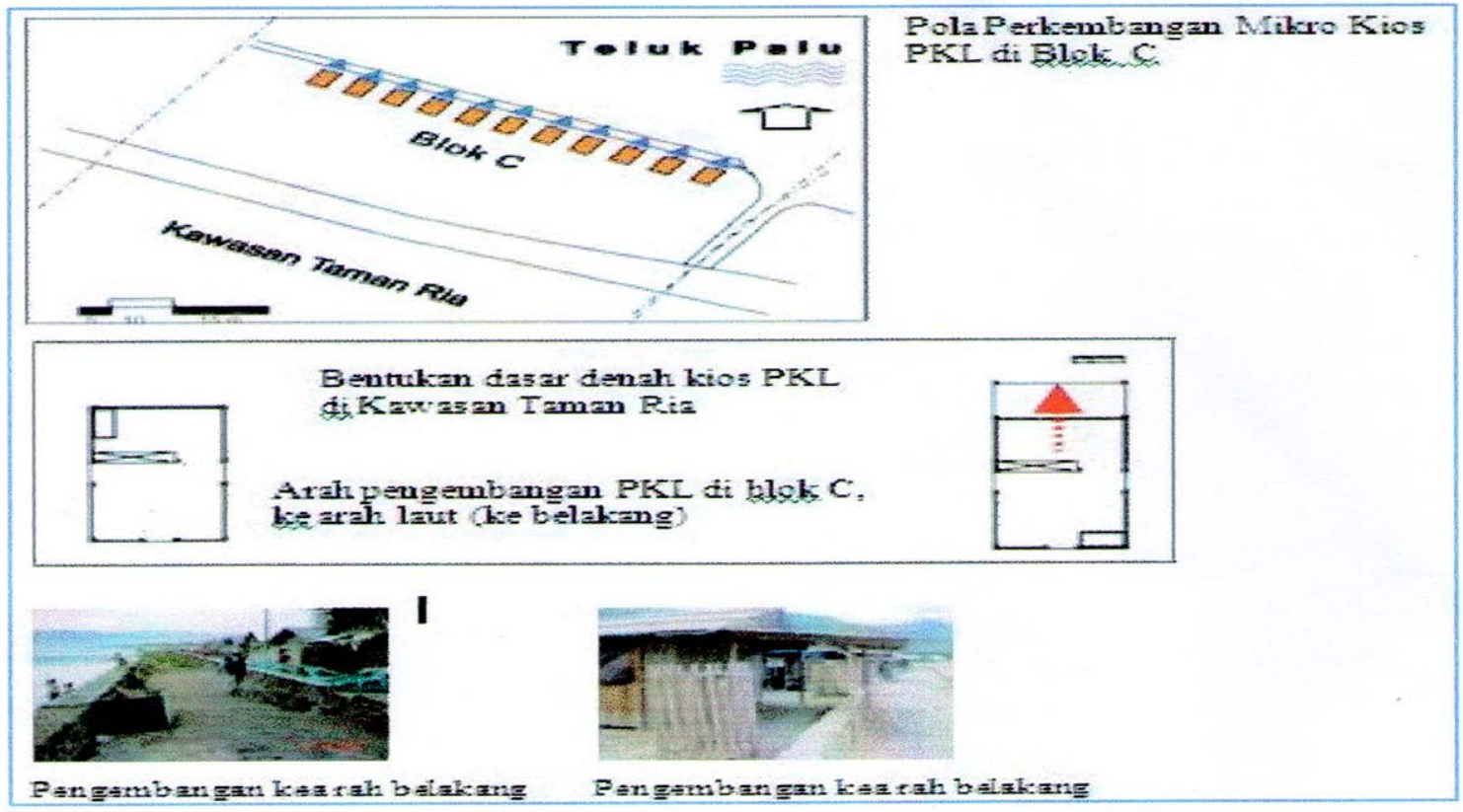

Gambar 7. Tampak Perkembangan Mikro Kios PKL di Blok C Sumber : Hasil analisis peneliti, 2004

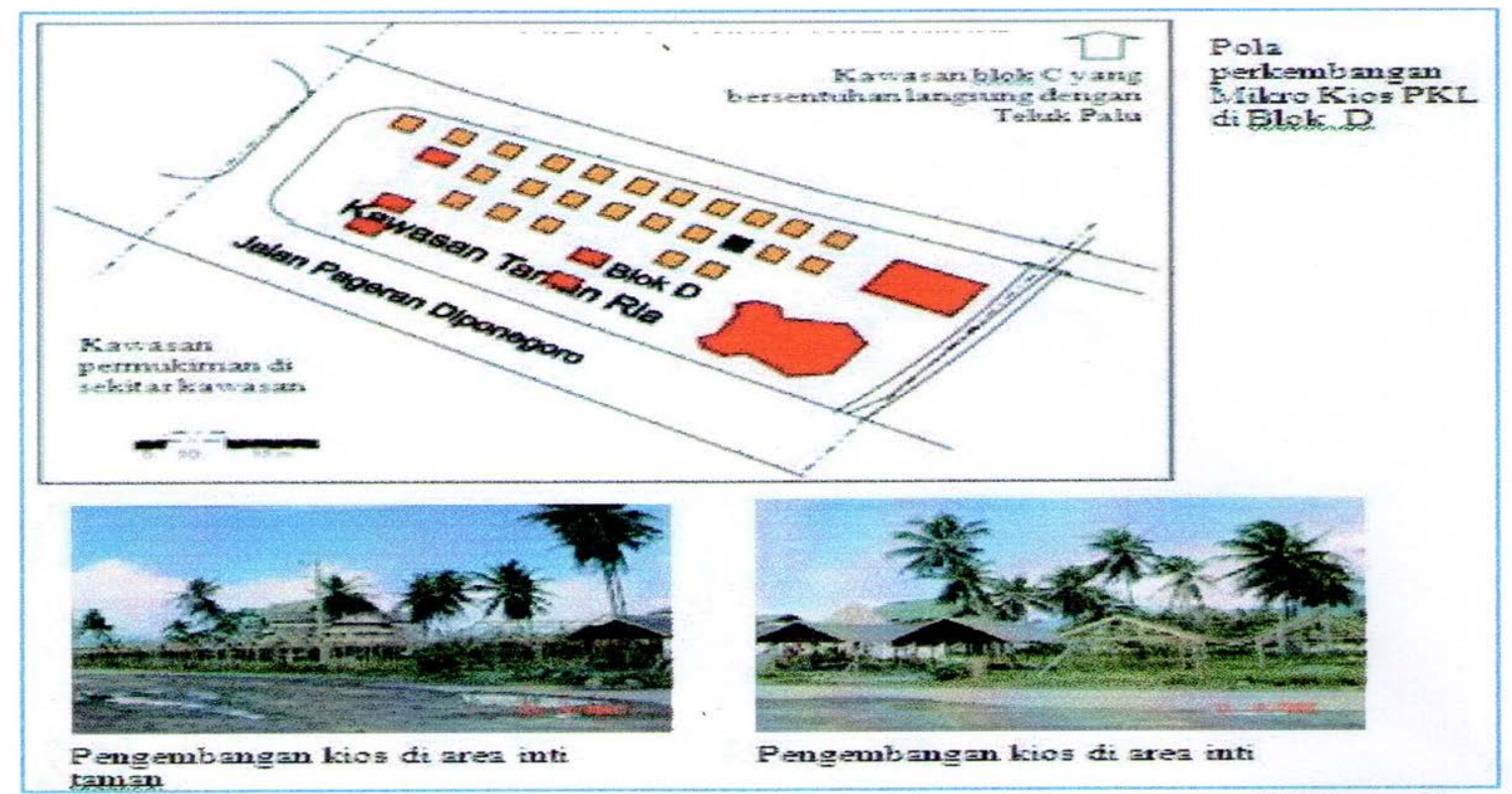

Gambar 8. Tampak Perkembangan Mikro Kios PKL di Blok D Sumber : Hasil analisis peneliti, 2004 
Tabel 1. Hasil Penelitian

\begin{tabular}{|l|l|l|l|}
\hline No: & \multicolumn{2}{|c|}{ Pertanyaan dan Permasalahan } & \multicolumn{1}{c|}{ Kesimpulan Penelitian } \\
\hline \hline 1. & Seperti apa pola Pedagang Kakilima di Kawasan Taman Ria & $\begin{array}{l}\text { - Pola perkembangan dipengaruhi oleh akses berupa jalan serta } \\
\text { Kapat di eliminasi sebagai berikut } \\
\text { Kedekatan dengan Pantai (Teluk Palu) }\end{array}$ \\
- Pola Pedagang Kakilima (PKL) cenderung berkelompok dengan \\
pola linier (menerus)
\end{tabular}

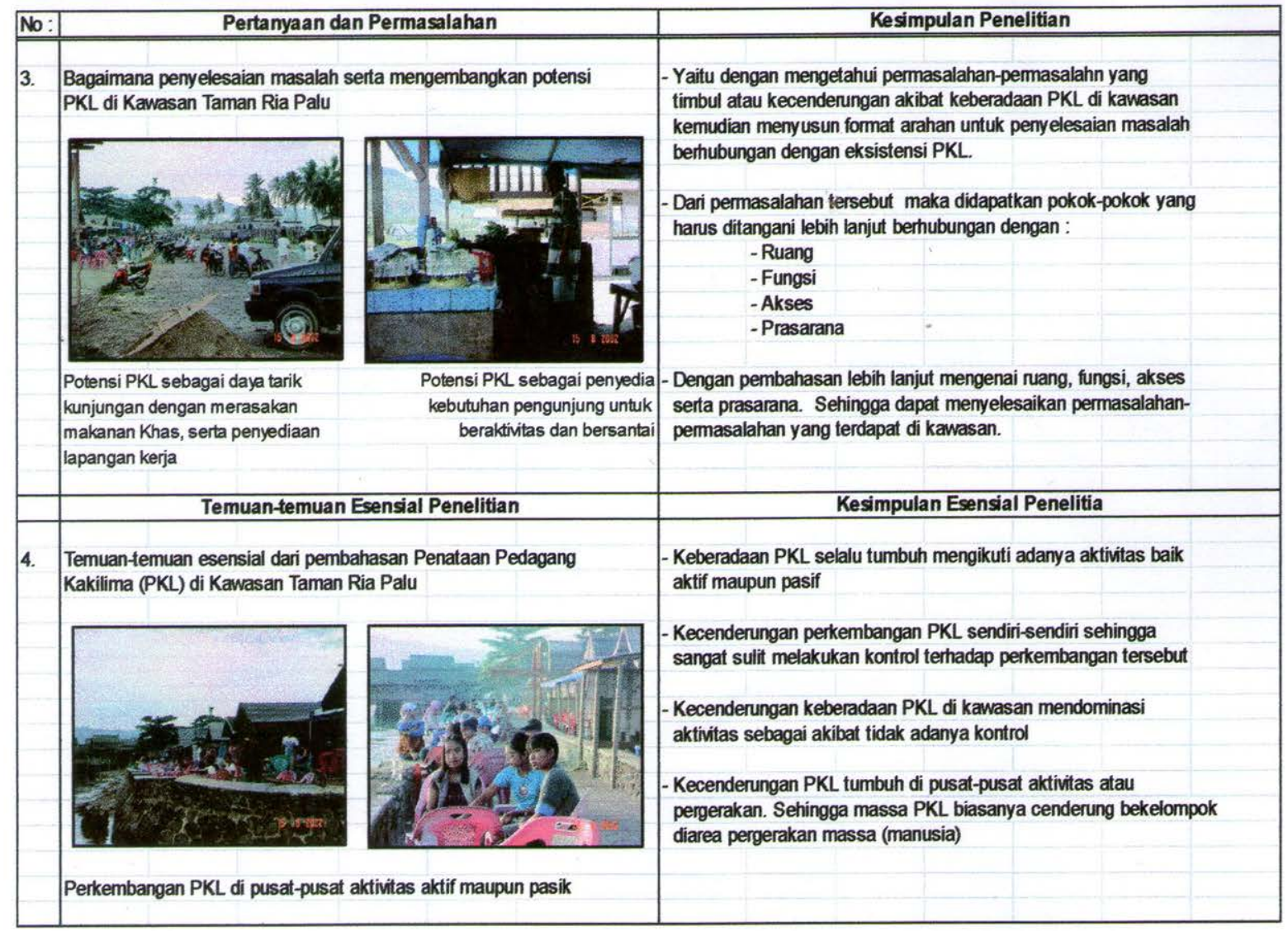

Nindyo Suwarno \& Muhammad Bakri : Penataan Pedagang Kaki Lima (PKL) Di 


\section{KESIMPULAN DAN SARAN}

Berdasarkan beberapa temuan analisis dan bahasan sehingga dapat dieliminasi dalam persoalan pengelolaan, pengunjung dan PKL sebagai satu kesatuan yang tidak terpisahkan. Di Kawasan Taman Ria Palu, pola perkembangan PKL dan masalah yang ditimbulkan yaitu :

1) Pola perkembangan PKL di pengaruhi oleh akses berupa jalan serta kedekatan dengan pantai sebagai objek pandang untuk bersantai.

2) Interfensi pemanfaatan ruang oleh aktivitas PKL dalam bentuk kelompok dengan pola linier mengikuti sirkulasi dan garis pantai sehingga ruang-ruang untuk aktivitas aktif/ pasif pengunjung tidak terpenuhi

3) Perkembangan PKL di Kawasan tidak memperhatikan interaksi antara elemen kawasan sehingga timbul kecenderungan PKL mendominasi kawasan dan menimbulkan kesan kumuh karena perkembangan yang tidak terkontrol

4) Aktivitas di kawasan cenderung memanfaatkan pantai sebagai tempat pembuangan sampah sehingga berdampak pada kebersihan lingkungan.

5) Tidak adanya singkronisasi antara kebutuhan pengunjung akan Kenyamanan, bersantai, melakukan aktivitas serta discovery dalam taman dengan keberadaan PKL sehingga timbul kesan PKL mematikan potensi kawasan sebagai taman publik.

Keberadaan PKL memunculkan masalah keruangan berhubungan dengan kegiatan individu atau kelompok yang bersifat aktif maupun pasif. Kegiatan tersebut mendorong perkembangan kios-kios PKL yang dimungkingkan karena tidak adanya format mengenai PKL di kawasan. Oleh karena itu perlu ditinjau kembali masalah yang timbul dengan kebaradaan PKL di Taman Ria untuk menyusun format arahan penataan hubungannya dengan pemanfaatan ruang untuk aktivitas PKL di golongkan elemen fisik dan non fisik meliputi :

1) Keruangan ; a. Berkurangnya ruang tempat melakukan, b. Berkurangnya area inti taman, c. Terhahalangnya pemandangan khususnya ke arah laut dan d. Sirkulasi pejalan kaki di pinggir pantai tertutupi.

2) Fungsi ; a. Perkembangan PKL yang tidak terkendali dan berangsurangsur menjadi tempat tinggal, $b$. Ketidakjelasan fungsi ruang.

3) Aksesibilitas ; a. Kurang terpenuhi kenyamanan akses, b. Semakin sempitnya jalur sirkulasi pejalan kaki, dan c. Tidak tersedianya tangga yang memungkinkan interaksi langsung ke pantai

4) Prasarana ; a. Fasilitas taman bermain untuk anak sebagian besar sudah rusak dan tidak difungsikan, b. Kurangnya vegetasi berakibat keteduhan kawasan kurang khusus area penggiran pantai, c. Tidak tersedianya fasilitas kebersihan, $d$. Fasilitas tempat duduk dan meja disediakan oleh PKL, e. Tidak tersedianya fasilitas tempat duduk yang terlindung dari terik matahari, f. Kurangnya fasilitas penerangan taman, dan Tidak tersedianya fasilitas umum.

\section{DAFTAR PUSTAKA}

1. Ashihara, Yoshinobu (1970), Exterior Design In Architecture, Van Nostrand Reinhold Company, New York.

2. Carr Stephen, Francis Mark, Rivlin G. Leanne, Stone M. Andrew (1992), 
Public Space, Cambridge University Press, Australia.

3. Garnham, Harry Launce (1985), Maitaining The Spirit of Place, PDA Publisher Corp., Mesa, Arizona.

4. Green B. Barrie (1977), Space, Dimension of the Human Landscape, Yale Universiy Press, London.

5. Hertzberger, Herman (1991) Lessons for students In Architecture. Rotterdam: Uitgeverij 010 Publishers.

6. Hidayat Arif (2001), Sosiologi Urban, PKL Aset atau Permasalahan Kota Bandung,MagisterManagemen STMB

7. International Symposium on Asian Pacific Architecture (1997), The Making Of Public Space, The School of Architecture, University of Hawai'i.

8. Morfosa Merry (2002), Faktor Yang Berpengaruh Pada Pemanfaatan Ruang Terbuka Publik Kawasan Pusat Kota, Thesis S2, Program Studi Teknik Arsitekture Konsentrasi Desain Kawasan Binaan, Universitas Gadjah Mada, Yogyakarta.

9. Muhadjir Noeng (2000), Metodologi Penelitian Kualitatif, Edisi ke IV, Rake Sarasin, Yogyakarta , Indonesia.

10. Porteous, J. Douglas (1977), Environment \& Behaviour, Planning and Everyday Urban life, Menlo Park, California, Addison Wesley Publishing Company.
11. Rapoport, Amos (1980) Human Aspect of Urban Form. Towards a Man-Environment Approach to Urban Form and Design. Pergamon Press.

12. Sarosa Wicaksono (2001), Menyoroti Sektor Informal Perkotaan, Research

13. and Development Director, Urban and Regional Development Institute.

14. Shimon Jhon Ormsbee (1997), Landcape Architecture, A manual of Site Planning and Design, McGraw-Hill Companies, New York.

15. Shirvani, Hamid (1985), The Urban Design Process, Van Nostrand Reinhold Company, New York.

16. Sukamdi (1998 / 1999), Studi Pengembangan SDM Pekerja Sektor Informal di Daerah Istimewa Yogyakarta, Pusat Penelitian Kependudukan Univesitas Gadjah Mada, Yogyakarta.

17. Whyte, H. William (1988), The Social Life of Small Urbane Spaces, The Conservation Foundation, Washington, D.C.

18. ------ (1999-2009), Rencana Tata Ruang Wilayah Kotamadya Palu, Badan Perencanaan Pembangunan Daerah (BAPPEDA). 